Eva Sicherl,

University of Ljubljana

Andreja Žele,

Scientific Research Centre of the Slovenian Academy of Sciences and Arts

\title{
COMBINABILITY WITH PREPOSITIONS IN SLOVENE AND ENGLISH: THEORETICAL AND CONTRASTIVE VIEWS
}

The present article aims to shed some light on the combinability of verbs, nouns and adjectives with prepositions - a phenomenon which is common both in Slovene and in English, but has not been extensively commented on by Slovene linguists. In AngloAmerican linguistics, such combinations with prepositions are basically divided into two groups, which tend to be named differently by authors of different linguistic "orientations".

Keywords: semantic- and structural-syntactic aspect of valency, combinability with prepositions, prepositional free morpheme, prepositional collocation, free combination

\section{Introduction}

Valency theory, originating in dependency grammar as developed by Tesnière (1959) and particularly developed in the 1960s and 1970s by German linguists (e.g. Helbig, Schenkel, Heringer, Schumacher, Engel), has also found its place in Slovene linguistics. A rather complex multi-level treatment of valency from the semantic- and structural-syntactic aspect (with an original orientation from form to meaning and vice versa and with account taken of transformational grammar linguistics) is found as early as the second half of the 1970s in Toporišic (1976). Approximately at the same time valency in Slovene was dealt with by the French author Vincenot in his grammar Essai de Grammaire Slovène (1975). In the following years, valency was treated in more detail and depth by Toporišič (1982), as well as by Dular (1982), Križaj (1981, 1982, 1989), and Vidovič Muha (1993), who all researched the transformational grammar aspect of valency more intensively. Kunst Gnamuš (1981) and Orešnik (1992) have contributed to shaping the theory of Slovene valency with a more exact treatment of the semantic composition of the utterance and by presenting semantic orientation. These two works rely theoretically and methodologically on Anglo-American studies ${ }^{1}$ and treat valency within the framework of the semantic level.

\footnotetext{
${ }^{1}$ Mainstream Anglo-American linguistics has largely neglected the findings of valency theory, but has often gone parallel ways to describe the same phenomena (cf. Herbst and Roe 1996: 179-180). Nevertheless, several attemps have been made to apply the concept of valency to English (e.g. Emons 1974, 1978), Matthews (1981), Allerton (1982), Herbst (1983, 1988), Somers (1984), von Randow (1986)).
} 
One aspect of valency pertains to complementation of verbs (but also of nouns and adjectives) by prepositions. The present article aims to shed some light on this phenomenon, which is common both in Slovene and in English, but has not been extensively commented on by Slovene linguists. In Anglo-American linguistics, such combinations with prepositions are basically divided into two groups, which tend to be named differently by authors of different linguistic "orientations" (cf. Herbst and Roe 1996: 180), yet most of them seem to agree that the key issue lies in the obligatoriness of the preposition and its dependence on the lexical word. Most speakers of either of the languages thus tend to "feel" there exists a difference between sentences like:

\section{John lectures on \| semantics. Janez predava o \| semantiki. John lectures $\|$ on Fridays. Janez predava \| ob petkih.}

In the first sentence, the link between the lexical word (verb) and the following preposition is felt to be stronger than is the case with the combination in the second sentence. In the latter sentence, the phrase boundary comes after the verb, and the preposition with the following noun forms a (prepositional) phrase. The latter combinations are usually referred to as free combinations of lexical words with prepositions; they are constructed in accordance with general syntactic rules and freely allow substitution (e.g. John lectures $\|$ in the classroom, John lectures $\|$ from five to six thirty I Janez predava || v razredu, Janez predava || od petih do pol sedmih). The former combinations may be referred to as collocations ${ }^{2}$ consisting of a lexical word (a verb/noun/adjective forming the base of the unit) and a preposition (functioning as the collocator); this type of word combination could also be named 'prepositional collocation' (cf. Sicherl 1999, 2004). Prepositional collocations can thus be defined as typical, recurrent combinations of verbal, nominal or adjectival bases with prepositional collocators. $^{3}$

However, the distinction between the two groups is not always clear cut - while some cases may be immediately classified as either prepositional collocations or prepositional free combinations, others may prove to be extremely unclear and vague, and there are many borderline cases which may satisfy some of the syntactic criteria ${ }^{4}$ for inclusion among prepositional collocations but not others. Semantic criteria for dis-

\footnotetext{
$\overline{2}$ Hausmann (1985: 178) defined collocations as "typical, specific and characteristic two-fold relationships between words" (typische, spezifische und charakteristische Zweierbeziehungen von Wörtern). Characteristically, collocations are not produced creatively by the speaker as are free combinations; rather, they are retrieved from the speaker's memory as combinations forming a unit, as some kind of language "semiproducts". Another typical trait is a relationship of affinity between the two words forming a collocation, so that they often appear together (see also Hausmann 1984: 398 and Bahns 1996: 24).

3 In The BBI Dictionary of English Word Combinations such combinations are referred to as a subclass of grammatical collocations (see categories $G 1, G 5$ and $G 8 D$ in Benson, Benson, Ilson 1997: xvi, xviii, xxi).

4 These criteria were mainly defined by British and German linguists (for further details see, for example, Quirk et al. 1985: 1163 ff, Palmer 1988: 229-231, Schröder 1986: 13-22, Helbig and Schenkel 1975: 40-49, Lerot 1982: 263-265), and include the choice of the question form, possibility of passive transformation, possibility of cutting the prepositon off from the lexical verb in relative clauses and wh-questions, substitutability of preposition, etc.
} 
tinguishing between free combinations and prepositional collocations seem to be even more elusive, ${ }^{5}$ yet they often prove decisive for inclusion in one group or the other, especially when combined with the syntactic ones (see also Quirk et al. 1985: 1163). The distinction between the two categories remains to a certain extent arbitrary and subject to gradience.

The existence of different semantic-syntactic roles of prepositions in Slovene, however, was commented on already in the first Slovene grammar by Bohorič (1584); the author felt the preposition to be gravitating towards the verb in some cases, and towards the adverb in others. ${ }^{6}$ A survey of later Slovene grammars shows that the treatment of prepositions under either verbal or adverbial government is not accidental; rather, it suggests the authors' language feeling which made them treat governed prepositions as part of the verb, i.e. as free morphemes which help to form the meaning of the verb ${ }^{7}$, or, in other words, they perceived the entire combination as a prepositional collocation. However, the fact that Slovene as a synthetic language realizes cases by means of case inflections also has to be taken into account, and prepositional free morphemes can thus also be used to mark the case in the following free combination.

\section{Valency and Combinability with Prepositions}

Combinability with prepositions is related to valency on the morpho-syntactic level. Thus, the prepositional free morpheme (as described by Helbig 1984, 1992) which combines with a content or lexical word (usually a verb, but also a (morphologically related) adjective or noun) can be said to primarily modify the meaning of the lexical word it co-occurs with. The preposition is used to "direct" the verbal (adjectival or nominal) meaning; however, the morphological extension (the addition of a preposition to a lexical word) can also introduce new lexemic meanings, which results in new lexemes. The following examples may illustrate this point:

\footnotetext{
5 Naturally, since the borders between the two groups remain fuzzy, no hundred-percent agreement can be expected between different analysts as to the inclusion of certain cases in either of the two groups. Thus, for example, the degree of metaphoricalness or idiomaticity may influence our decision. If "disagree with" as used in the sentence Orange juice seems to disagree with some babies. is perceived as a prepositional collocation, does the same hold true for "disagree with" in the sentence I respect the president but I disagree with his decision ... (illustrative sentences taken from Collins Cobuild English Dictionary 1995: 464), or is the latter a free combination? It seems that the verb "disagree" when used with an inanimate subject becomes semantically specialized and is therefore often treated differently from "disagree" with an animate subject. In such cases obviously the context, and not the word combination itself, causes semantic modification which may result in a different classification. Other factors which may influence our analysis, apart from the combination of strictly semantic and syntactic ones, are also usage and frequency.

6 Bohorič (see Toporišič ed. 1984: 258) used the terms "dostavljen" and "pristavljen" and classified prepositions according to the cases they govern based on Latin patterns, quoting examples such as od Buga, pres njega, s'Bugom, Jkriv fhi pred ozhetom. The preposition, according to Bohorič, is either syntactico-semantically closely related to the verb ("dostavljen") or just added to it ("pristavljen"). Centuries later, Toporišič (1976) introduced the terms "vezavnovezljiv" and "vezavnodružljiv".

7 In his description of the Slovene language, Gutsman (1777: 110-111) makes a distinction between sentences like Je v'Zelovzi rojen, Mi jmo vu Velikouzi prebivali, Eni fe v'Doberleve Js, eni pak v'Tershizh popelajo and sentences such as On je sa frednika med nami biu poftaulen, On bo sa mieftnega fodnika svolen gratau.
} 


\begin{tabular}{|l|l|}
\hline Počakati moram. & I need to wait. \\
\hline Počakati moram na šolski avtobus. & I need to wait for the school bus. \\
\hline Tone je prišel. ('prispeti') & Tony has come. ('arrive') \\
\hline Tone je prišel do odločitve. ('odločiti se') & Tony has come to a decision. ('decide') \\
\hline
\end{tabular}

While the Slovene language is generally oriented into using the direct accusative, it tends to express itself more accurately and analytically by using combinations with prepositions (cf. Žele 2001). English as an analytic language seems to depend on prepositions to an even greater degree; there prepositions are, like other grammatical items, primarily used to mark the syntactic relation between lexical words forming a construction (cf. also Lyons 1968: 435-438 and Collinge 1990: 144). However, the semantic distinction between the illustrative sentences cited below seems to be identical in both languages:

\begin{tabular}{|l|l|}
\hline Streljali so zajce. & They shot rabbits. \\
\hline Streljali so na zajce. & They shot at rabbits. \\
\hline
\end{tabular}

When the direct accusative is used with the verb shoot/streljati, the sentences imply that the rabbits were either killed or injured. When the verb is combined with the preposition at/na, the preposition introduces the meaning of 'orientation/direction' of the shooting, without implying the result of the action.

When used in combinations, prepositions form part of the semantic content of verbs, nouns and adjectives (particularly those nouns and adjectives which are morphologically related to the corresponding verbs) they combine with. When a preposition enters into a combination with a lexical word, it either helps form the meaning of the entire combination (resulting in lexicalization ${ }^{8}$ of the whole) or merely adds some stress to the lexical word.

\begin{tabular}{|l|l|}
\hline $\begin{array}{l}\text { Zivi skupaj s psom. ('deliti si življenjski } \\
\text { prostor') }\end{array}$ & $\begin{array}{l}\text { He lives with his dog. ('share a living } \\
\text { place with') }\end{array}$ \\
\hline $\begin{array}{l}\text { Zivel je } \mathbf{z} \text { njo, še preden sta se poročila. } \\
\text { ('Živeti v partnerstvu') }\end{array}$ & $\begin{array}{l}\text { He lived with her before they got mar- } \\
\text { ried. ('live together as if married') }\end{array}$ \\
\hline
\end{tabular}

A practical and useful differentiation between free combinations with prepositions and grammatical, or, to be more precise, prepositional collocations taken from AngloAmerican linguistics may be parallelled to the classification of combinations with prepositions as used by Slovene linguists. However, the distinction between the two

8 The term lexicalization is used here to denote that the preposition becomes part of the meaning of the lexical word; a syntactic unit consisting of a lexical word and a preposition becomes a dictionary unit, a multi-word lexeme. 
categories is subject to gradience. Prepositional collocations can be regarded as results of natural semantic- and structural-syntactic combining of words, as mutual semantic and syntactic expectancy of words. ${ }^{9}$ When used in collocations or in free combinations, the prepositions usually express those semantic components which tend to participate in valency both semantically and syntactically. Prepositions thus help express intentional/valency-related semantic components of verbs, nouns or adjectives also in structural-syntactic terms. Prepositions express more clearly the mutual dependency between the semantic component of a verb/adjective/noun and its valency, or, in other words, they show the reverse effect valency has on the semantic structure of a verb/adjective/noun. ${ }^{10}$ It needs to be stressed, however, that in prepositional collocations the two-way semantic-syntactic affinity observed between the lexical word and the preposition (cf. Sicherl 2004: 44) is not equally strong: the one leading from the dominant lexical word to the preposition is felt to be much stronger than the one leading from the preposition to the lexical word. The mutual expectancy therefore seems to work more strongly from the lexical word to the preposition than vice versa. The following pairs of Slovene and English equivalents may illustrate this point:

\begin{tabular}{|l|l|}
\hline povabiti na (zabavo) & invite to (a party) \\
\hline jezen na (mamo) & angry at (Mum) \\
\hline prepir o (politiki) & argument over (politics) \\
\hline
\end{tabular}

Naturally, such mutual semantic-syntactic ties are to be found in other languages as well and are not characteristic of Slovene or English only. However, they make a particularly interesting subject of study when viewed contrastively. While free combinations with prepositions seem relatively straightforward and unproblematic when two languages such as English and Slovene are contrasted ${ }^{11}$, the mutual semanticsyntactic ties existing between the verbal/nominal/adjectival base and the prepositional collocator in collocations are more interesting to observe, particularly when the same base can be combined with several different prepositions with little or no change in meaning. The addition of the prepositional collocator stresses a certain semantic component, and, usually, also introduces valency. Thus, for example, the Slovene preposition $n a$ introduces the semantic component of 'expectation' in combinations such as pripraviti se na, čakati na, upati na, etc.; in English, there are prepositional

9 In linguistics, the mutual semantic and syntactic expectancy of words could only be subjected to adequate research in the last decades of the $20^{\text {th }}$ century when extensive computerized corpora of over ten million words enabled analysts to collect relevant data on the basis of which a certain word combination could be classified as a collocation with more certainty. However, statistical data cannot be the only criterion for the inclusion of a combination among collocations.

10 Prepositions combined with verbs, particularly those lexicalized, are treated in the Slovar slovenskega knjižnega jezika (1975-1991) in the form of notes on grammatical patterns: "s predložnim povedkovim določilom" [used with a prepositional subject complement]; "s predložno zvezo" [used with a prepositional phrase]; "s predlogom" [used with a preposition]; "v zvezi z/s" [followed by the preposition s/z].

11 For more on this, see Sicherl (1999). 
collocations with for carrying a similar meaning, as in prepare for, wait for, hope for, etc. And, similarly, German equivalents of those bases tend to combine with the preposition auf to introduce 'expectation' as in sich vorbereiten auf, warten auf, hoffen auf, etc.

\begin{tabular}{|l|l|l|}
\hline Pripravil se je na izpit. & He prepared for the exam. & $\begin{array}{l}\text { Er bereitete sich auf das } \\
\text { Examen vor. }\end{array}$ \\
\hline Cakal je na vlak. & He waited for the train. & Er wartete auf den Zug. \\
\hline $\begin{array}{l}\text { Upal je ma pozitiven } \\
\text { rezultat. }\end{array}$ & $\begin{array}{l}\text { He hoped for a positive } \\
\text { result. }\end{array}$ & $\begin{array}{l}\text { Er hoffte auf ein positives } \\
\text { Resultat. }\end{array}$ \\
\hline
\end{tabular}

Another example to illustrate the above point is provided by prepositional combinations in which the verbal/nominal base carries the meaning of 'intellectual activity' while the combining preposition is used to introduce the 'theme/content' of this intellectual activity. The preposition used in Slovene in these combinations is typically $o$, in English it is substituted by on (with alternative combining options possible in several cases, such as about, concerning, over, of) with bases of the same or a similar meaning, while German tends to use the preposition über with most equivalents:

\begin{tabular}{|l|l|l|}
\hline $\begin{array}{l}\text { Prosili so ga, naj spregovori } \\
\text { o pomembnosti umetnosti ve was asked to talk on } \\
\text { izobraževanju. }\end{array}$ & $\begin{array}{l}\text { Er wurde gebeten, über die } \\
\text { the importance of arts in } \\
\text { education. }\end{array}$ & $\begin{array}{l}\text { Bedeutung der Kunst im } \\
\text { Unterrricht zu sprechen. }\end{array}$ \\
\hline $\begin{array}{l}\text { Napišite spis o napredku } \\
\text { civilizacije. }\end{array}$ & $\begin{array}{l}\text { Write an essay on the } \\
\text { advance of civilization. }\end{array}$ & $\begin{array}{l}\text { chreiben Sie einen Aufsatz } \\
\text { über den Fortschritt der } \\
\text { Zivilisation. }\end{array}$ \\
\hline
\end{tabular}

\section{Classification of Prepositions Used in Combinations}

Prepositions used in combinations have developed out of spatial (and temporal) adverbs which define an action more accurately, so it is not surprising that their primary semantic-syntactic position is next to the verb. In Slovene linguistics, verbalprepositional combinations can be classified into the following three types (according to Žele 2001): ${ }^{12}$

a) lexicalized verbal-prepositional combinations

b) non-lexicalized verbal-prepositional combinations

c) verbal-prepositional free combinations

A preposition is lexicalized when it semantically co-forms the meaning of the verb.

12 Enciklopedija slovenskega jezika (Toporišič 1992: 230,351) distinguishes between "predložni vezavni morfem" [prepositional morpheme] and "prosti morfem" [free morpheme]. See also Švedova (1980: 156) for Russian. Žic Fuchs (1991: 123) mentions J.M. Anderson's classification into "inherent lexical content", which corresponds to the lexicalized verbal-prepositional combination in semantic-syntactic terms, and "derived lexical content", the latter corresponding to non-lexicalized verbal-prepositional combination in semantic-syntactic terms. 
The preposition in such a lexicalized combination thus behaves as if it were an "inherent" part of the verb (cf. also Dixon 1991: 268); it becomes part of the verbal lexeme as a dictionary unit and, simultaneously, part of this verb's valency. A preposition is said to be non-lexicalized when it is semantically related to (usually) only one sense of the verbal lexeme and expresses its semantic- and structural-syntactic valency.

\begin{tabular}{|l|l|}
\hline $\begin{array}{l}\text { Delal je na projektu. ('ustvarjati') } \\
\text { LEXICALIZED VERBAL-PREP. COMBINATION }\end{array}$ & $\begin{array}{l}\text { He worked on the project. ('have sth as } \\
\text { the subject of thought') PREP. COLLOCA- } \\
\text { TION }\end{array}$ \\
\hline $\begin{array}{l}\text { Delal je na polju. ('obdelovati, kmeto- } \\
\text { vati') NON-LEXICALIZED verked in the fields. ('grow crops') } \\
\text { COMBINATION }\end{array}$ & \begin{tabular}{l} 
FREE COMBINATION \\
\hline
\end{tabular}
\end{tabular}

A lexicalized preposition is bound to the entire meaning of the multi-word unit (dictionary unit) it co-forms with the lexical word, a non-lexicalized preposition is bound only to one sense of the dictionary unit.

The differentiation between lexicalized and non-lexicalized prepositions in Slovene can also be illustrated by delexical primary verbs. The preposition is lexicalized in the following combinations where the verb is delexical, or rather, does not carry a full lexical meaning. Semantically equivalent English sentences do not necessarily use a prepositional combination.

\begin{tabular}{|l|l|}
\hline Bil je ob hišo. ('izgubiti') & He lost his house. \\
\hline Imel jo je za pametno. ('ceniti kot') & He regarded her with respect. \\
\hline Dala je na njegov nasvet. ('upoštevati') & She paid attention to his advice. \\
\hline
\end{tabular}

Below, the preposition is non-lexicalized; it is combined with the verb with a full lexical meaning. Again, parallel semantically equivalent English combinations are given, yet they do not always use a combination with a preposition:

\begin{tabular}{|l|l|}
\hline Bil je ob hiši. ('nahajati se') & He was next to the house. ('stand') \\
\hline Prihranke je imell za slabe čase. ('hraniti') & He kept his savings for hard times. ('set aside') \\
\hline Krožnike je dal na mizo. ('položiti') & He put the plates on the table. ('place') \\
\hline
\end{tabular}

Analyzing the above combinations from the point of view of the collocation - free combination dichotomy, the non-lexicalized are mainly free combinations, while the lexicalized can pass for collocations.

2.1 The lexicalization of the preposition in combination with a full (specialized) non-primary verb can neutralize the meaning of that verb. Along with the neutralization of the original, specialized verbal meaning, the addition of a preposition results in transitivization of the lexicalized unit, and often gives the combination an additional 
tenor in terms of register, formality, etc.

\begin{tabular}{|l|l|}
\hline Tista kača se je že levila. & That snake has already shed its skin. \\
\hline Janez se levi v pravega podjetnika. & John is turning into a proper businessman. \\
\hline Pri izgovorjavi težkih besed se je zapletel. & $\begin{array}{l}\text { When pronouncing difficult words he } \\
\text { stumbled. }\end{array}$ \\
\hline Zapletel se je v umazane posle. & He got mixed up in some shady business. \\
\hline
\end{tabular}

With some other verbs, the addition of a preposition merely changes the valency of the verb in semantic- and structural-syntactic terms.

\begin{tabular}{|l|l|}
\hline Kokoš vali jajca. & The hen hatches her eggs. \\
\hline Vedno je vallil krivdo na koga drugega. & $\begin{array}{l}\text { He always shifted the blame onto some- } \\
\text { body else. }\end{array}$ \\
\hline Ponudba še velja. & The offer still holds. \\
\hline Velja za poštenjaka. & He is believed to be an honest man. \\
\hline
\end{tabular}

Syntactic characteristics of lexicalized prepositional combinations:

1) The preposition introduces rightward valency

a) when combined with originally intransitive verbs

Prišlo je do vojne.

It came to war.

Spustil se je $\mathbf{v}$ dolgo razlago, zakaj me He went into a long explanation of why mora videti. he had to see me.

b) when combined with primary verbs

Še boš moral delati na šibkih točkah/You will have to work on the weak points svoje slovenščine. in your Slovene.

\begin{tabular}{|l|l} 
Nenadoma je bill ob vse svoje bogastvo. & He suddenly lost all his fortune. ${ }^{13}$
\end{tabular}

c) when combined with verbs of motion; the preposition in these combinations retains the meaning of orientation, and gives a secondary, metaphorical meaning (of phaseness of action/characteristic/state or of relation of action) to the verbal base.

\begin{tabular}{|l|l|}
\hline Oddaljil se je od teme. & He digressed from the subject. \\
\hline Planili so po sovražniku. & They fell on the enemy. \\
\hline Dan se je prevesil v noč. & The day turned into night. \\
\hline Nehaj dregati vame! & Stop picking on me. \\
\hline Pes se je spravil nad lastnega gospodarja. & The dog turned on his own master. \\
\hline
\end{tabular}

13 The English equivalents of the Slovene illustrative examples of lexicalized prepositional combinations given here may not be constructed on the same pattern and may lack a prepositional combination altogether. 
2) Combinability with prepositions can also result in generalization of the verbal meaning, as in:

a) purpose(fulness)/intensity of action/state

b) conclusion of action

c) excitement or diligence

d) intrusiveness

e) active/passive relationship or acquisition or use

\begin{tabular}{|l|l|}
\hline $\begin{array}{l}\text { a) Moral se bo vreči na delo. } \\
\text { Zakopal se je v študij. }\end{array}$ & $\begin{array}{l}\text { He will need to bury himself in his work. } \\
\text { He dug into his studies. }\end{array}$ \\
\hline b) Vstala je od mize. & She rose from the table. \\
\hline c) Zagorel je za novo idejo. & He burned with excitement for the new idea. \\
\hline d) Tiščali so vanj, pa jim ni povedal. & $\begin{array}{l}\text { They plied him with questions, but he } \\
\text { refused to tell them anything. }\end{array}$ \\
\hline e) Zivi od pisanja knjig. & She manages to live on her writing. \\
\hline
\end{tabular}

3) The preposition can change the meaning of an originally transitive verb and thus also its rightward valency:

\begin{tabular}{|l|l|}
\hline Konj je vlekel voz. & The horse pulled the cart. \\
\hline Barva je vlekla ma zeleno. & The colour was greenish. \\
\hline
\end{tabular}

4) The preposition causes semantic transition to a non-spatial evaluation of the state:

\begin{tabular}{|l|l|}
\hline Nagibal se je čez ograjo. & He leaned across the fence. \\
\hline Nagibajo se k praktičnim rešitvam. & They tend to lean towards practical solutions. \\
\hline
\end{tabular}

5) The preposition stresses a characteristic of an actant:

\begin{tabular}{|l|l|}
\hline Visel je med življenjem in smrtjo. & He hovered between life and death. \\
\hline Fantje so se kar lepili nanjo. & The boys were really stuck on her. \\
\hline
\end{tabular}

2.2 A non-lexicalized preposition in a combination retains its spatial meaning or has at least some orientational meaning. As part of verbal valency, a non-lexicalized preposition can be obligatory and introduce the so-called "partially obligatory verbal valency" (cf. also Samardžija 1986: 119).

\begin{tabular}{|l|l|}
\hline $\begin{array}{l}\text { Od včeraj leži v bolnišnici. } \\
\text { ('biti hospitaliziran') }\end{array}$ & $\begin{array}{l}\text { He's been in hospital since yesterday. } \\
\text { ('be hospitalized') }\end{array}$ \\
\hline
\end{tabular}

It is precisely within the group of non-lexicalized prepositional combinations that the boundary between prepositional collocations and free combinations with prepositions as known from Anglo-American linguistics can be drawn. However, this bound- 
ary is often hard to define and remains fuzzy. Nevertheless, it can be said that in most cases non-lexicalized combinations with prepositions either introduce or retain valency and form some kind of non-idiomatic prepositional collocations.

\section{Syntactic characteristics of non-lexicalized prepositional combinations:}

1) The preposition introduces new participant roles, making what was originally a rather general meaning of the verb more precise and concrete:

a) prepositions combined with verbs of oriented control, transfer, introduction/continuation, limitation, prevention tend to have an orientational meaning

\begin{tabular}{|l|l|}
\hline Poslal je sporočilo. & He sent a message. \\
\hline Poslal je sporočilo po elektronski pošti. & He sent a message by e-mail. \\
\hline Nadaljeval je. & He continued. \\
\hline Nadaljeval je $\mathbf{z}$ razpravo. & He continued with the discussion. \\
\hline
\end{tabular}

b) prepositions combined with verbs of motion retain a spatial meaning of aim or target

\begin{tabular}{|l|l|}
\hline Zdrsnil je. & He slipped. \\
\hline Drsel je v depresijo. & He sank/slid into depression. \\
\hline
\end{tabular}

c) prepositions may render the meaning of end of state

\begin{tabular}{|l|l|}
\hline Prebudil se je. & He woke (up). \\
\hline $\begin{array}{l}\text { Potrebuje nekaj časa, da se prebudi iz } \\
\text { nočnega spanca. }\end{array}$ & $\begin{array}{l}\text { It takes him some time to wake from his } \\
\text { night's sleep. }\end{array}$ \\
\hline
\end{tabular}

2) Prepositions combined with prefixed verbs of motion in Slovene tend to be homonymous with the prefix used in the verb; such prepositions introduce a certain "orientational valency":

\begin{tabular}{|l|l|}
\hline Vstopil je v stranko. & He joined the party. \\
\hline Sonce zahaja za gorami. & The sun sets behind the mountains. \\
\hline
\end{tabular}

3) The preposition can act as a permanent (stylistically neutral) free morpheme combining with a verb, the two making up a prepositional collocation. These combinations are particularly interesting to compare when the preposition is either used explicitly to express spatial meaning (the combination is non-lexicalized) or has a changed, figurative meaning (the combination is lexicalized). 


\begin{tabular}{|l|l|}
\hline $\begin{array}{l}\text { Njegova parcela meji na športno dvora- } \\
\text { no. ('biti na meji z' - NON-LEXICALIZED) }\end{array}$ & \\
\hline $\begin{array}{l}\text { Njeno obnašanje meji na blaznost. ('biti land borders on the sports hall. } \\
\text { zelo podoben' - LEXICALIZED) }\end{array}$ & Her behaviour verges on madness. \\
\hline
\end{tabular}

4) The preposition is optional with some verbs whose meanings already include 'purpose' or 'aim'; in the following illustrative sentences the Slovene prepositions na and $z a$ can be omitted without a change in meaning:

\begin{tabular}{|l|l|}
\hline Cakam (na) šolski avtobus. & I wait for the school bus. \\
\hline Igral je (na) flavto. & He played the flute. \\
\hline Pazila je (na) otroke. & She looked after the children. \\
\hline Pritisnil je (na) gumb. & He pressed the button. \\
\hline Lovil je (za) njegov rokav. & He grabbed at his sleeve. \\
\hline
\end{tabular}

In the above combinations, Slovene allows for variant forms (prepositional and nonprepositional), which testifies to the relative weakness of the link between the verb and the preposition. Consequently, this makes an ellipsis possible. A similar phenomenon can be observed in English, but usually a (slight) change of meaning is observable there:

He grabbed his sleeve. ('take something suddenly and roughly')

He grabbed at his sleeve. ('try to take/grab something')

He kicked the door. ('hit something forcefully with one's foot')

He kicked at the door. ('aim one's foot at something')

\section{The Influence of Prepositions on the Formation of Verbal Valency Groups in Slovene ${ }^{14}$}

In the following classification, the entire spectrum of combinations with prepositions as they appear in Slovene can be found, ranging from prepositional collocations proper to free combinations with prepositions. Again, their semantic equivalents in English may not be constructed on the same pattern and may lack a prepositional combination altogether.

3.1 With specialized verbs denoting physical or mental states the preposition stresses the state itself and/or the resulting characteristics

\begin{tabular}{|l|l|}
\hline Norčujejo se iz starega učitelja. & They make fun of the old teacher. \\
\hline Dvomi v njene sposobnosti. & He doubts her abilities. \\
\hline
\end{tabular}

3.2 Combined with specialized verbs denoting action/operation/creation, the preposition can express the prevalent semantic component, which is also the intentional/valency-related semantic component. The preposition thus introduces:

${ }^{14}$ For participant roles in the Slovene language see Orešnik (1992). 
a) enabling the originating/origin of something

Organizirajo kmete $\mathbf{z a}$ sodelovanje $\mathrm{z}$ They are helping to organize farmers to zadrugo.

work for the co-operative.

b) a stressed semantic component of motion

Odstranil je navlako $\mathbf{z}$ dvorišča.

He removed the junk from the yard.

c) a stressed semantic component of co-occurrence/co-appearing/appurtenance

\begin{tabular}{|l|l|}
\hline Pacienti čakajo (na) zdravnika. & The patients are waiting for the doctor. \\
\hline Caka ma ugodno priliko. & He's waiting for his chance. \\
\hline Sodelujejo $\mathbf{z}$ različnimi organizacijami. & They cooperate with various organizations. \\
\hline
\end{tabular}

d) a stressed semantic component of a change of property

\begin{tabular}{|l|l|}
\hline Pretvarjal se je v čudaka. & He was turning into a loony. \\
\hline
\end{tabular}

3.3 Combined with specialized verbs of communicating/thinking/understanding, the preposition introduces:

a) emphasis on 'receiving and having information'

\begin{tabular}{|l|l|}
\hline Dokumentiral je podatke s tabelami. & He tabulated the data.
\end{tabular}

b) emphasis on 'understanding and reacting to information'

\begin{tabular}{|l|l|}
\hline Projekt je argumentiral s številkami. & He backed up the project with statistics. \\
\hline
\end{tabular}

c) emphasis on 'giving information'

Agitirali so za kandidata.

They canvassed for the candidate.

3.4 Combined with specialized verbs with a general meaning of change, the preposition introduces emphasis on 'self-movement'.

\begin{tabular}{|l|l|}
\hline Navijači so se pulili za vstopnice. & The fans scrambled for tickets.
\end{tabular}

3.5 Combined with specialized verbs of movement, the preposition stresses:

a) the course of movement when used with a process verb;

b) the goalness of movement or purpose when used with a goal-directed verb;

c) the content of the event when used with an event verb.

\begin{tabular}{|l|l|}
\hline a) Vozi se v šolo. & He drives to school. \\
\hline b) Redno hodi na obiske. & He visits them regularly. \\
\hline c) Rad se vrača $\mathbf{k}$ domačim. & He likes to go back to his family. \\
\hline
\end{tabular}




\section{Contrastive View of Prepositions Used in Combinations}

A contrastive treatment of combinability with prepositions and valency patterns in two or even three different languages may often help shed some light on the characteristics of this phenomenon, outline potentially difficult areas in foreign-language learning as well as suggest techniques which may help sensitize users of a foreign language to divergences between their mother tongue and the foreign language.

While native speakers of a language may find prepositional collocations quite unproblematic as word associations of the collocational type are relatively uniform within one language community (cf. Herbst 1996: 389-390), these have proven to be one of the most difficult areas of linguistic knowledge to master for non-native speakers. To native speakers, collocations allow a certain degree of syntagmatic predictability which they have gradually learnt to master; however, non-native speakers, even very advanced ones, often lack this type of knowledge and end up combining their words in an untypical and unusual way. On the whole, it seems that Slovene learners of English, after having reached a certain level of proficiency, tend to have less difficulty producing free combinations than prepositional collocations (cf. Sicherl 1999) ${ }^{15}$. The reason for this may lie in the (changed, usually abstract and hardly definable) content of the preposition when this is used as collocator.

During recent decades linguists began to realize that even in the case of prepositional collocations we cannot talk of "semantic emptiness" (see Schröder 1986: 10), and that the choice of the preposition is semantically motivated (cf. also Dixon 1991: 271). It has become clear that in some collocations there is a possibility of variation in the preposition (e.g. talk of/about/on) without a radical change in meaning. That the preposition when used as a collocator acts, at least to some extent, as a carrier of meaning, can also be proven by valency patterns which the collocational bases enter. If these prepositions were entirely meaningless, we would probably not tend to combine meaning-related content words (collocational bases) with identical prepositions. However, in most cases, this is precisely what we do, and the emerging valency patterns turn out to be surprisingly uniform in the languages compared.

To illustrate this point, let us compare instances of prepositional collocations consisting of a verb/noun/adjective denoting sensations perceived through the nose by the olfactory nerves, and the following preposition which introduces a substance emitting an odour ${ }^{16}$. We can see that in English practically all these bases regularly combine with the preposition of; similar combinability with a preposition seems to be present in

15 Typically, Slovene speakers of English opt for that English preposition to combine with a lexical word which is "nearest" to the prototypical meaning of the Slovene preposition used in the semantically equivalent Slovene combination. Since the English preposition for is felt to be the nearest semantic equivalent of the Slovene preposition $z a$, they tend to "translate" the combination značilen za as *typical/characteristic for and not as typical/characteristic of. Even when there is a choice between two prepositions in English with little or no change in meaning, they usually select the one that is felt to be semantically nearer to the Slovene preposition: thus, an accidental sample of 33 advanced students of English at Ljubljana University preferred the combinations fair to (63\%), suited for (91\%) and rich with (47\%) to the combinations fair on (6\%), suited to $(3 \%)$ and rich in $(44 \%)$ as translation equivalents of the Slovene combinations pravičen do (otrok), primeren $z a($ delo) and bogat $z$ (vitamini).

16 The illustrative sentences below were taken from various sources found in the Internet and simplified by the authors. 
other languages as well. Below, comparison has been made with Slovene and German, where most verbal, nominal, and adjectival semantic equivalents of the English bases regularly combine with the prepositions po and nach respectively.

\begin{tabular}{|c|c|c|}
\hline $\begin{array}{l}\text { His room smelled of his } \\
\text { dog. }\end{array}$ & $\begin{array}{l}\text { V njegovi sobi je dišalo po } \\
\text { psu. }\end{array}$ & $\begin{array}{l}\text { Das Zimmer roch nach } \\
\text { seinem Hund. }\end{array}$ \\
\hline $\begin{array}{l}\text { The pale blue flowers } \\
\text { scented of almonds. }\end{array}$ & $\begin{array}{l}\text { Svetlomodri cvetovi so } \\
\text { dehteli po mandljih. }\end{array}$ & $\begin{array}{l}\text { Die blauen Blüten dufteten } \\
\text { nach Mandeln. }\end{array}$ \\
\hline $\begin{array}{l}\text { My clothes were stinking } \\
\text { of tobacco. }\end{array}$ & $\begin{array}{l}\text { Moja obleka je smirdela po } \\
\text { tobaku. }\end{array}$ & $\begin{array}{l}\text { Meine Klamotten stanken } \\
\text { nach Tabak. }\end{array}$ \\
\hline $\begin{array}{l}\text { The cabin reeked of } \\
\text { kerosene. }\end{array}$ & $\begin{array}{l}\text { V kabini je zaudarjalo po } \\
\text { kerozinu. }\end{array}$ & $\begin{array}{l}\text { Im Cockpit roch es mach } \\
\text { Kerosin. }\end{array}$ \\
\hline $\begin{array}{l}\text { An odour of lemons was } \\
\text { left in the room. }\end{array}$ & $\begin{array}{l}\text { V sobi je ostal vonj po } \\
\text { limonah. }\end{array}$ & $\begin{array}{l}\text { Im Zimmer blieb der Duft } \\
\text { nach Zitronen. }\end{array}$ \\
\hline $\begin{array}{l}\text { The male was attracted by } \\
\text { the natural scent of a female. }\end{array}$ & $\begin{array}{l}\text { Samca je privabil duh po } \\
\text { samici. }\end{array}$ & $\begin{array}{l}\text { Der Geruch nach Weib- } \\
\text { chen zog das Männchen an. }\end{array}$ \\
\hline $\begin{array}{l}\text { Try to remove the smell of } \\
\text { vomit from your carpets. }\end{array}$ & $\begin{array}{l}\text { Poskusite odstraniti smrad } \\
\text { po bruhanju iz preprog. }\end{array}$ & $\begin{array}{l}\text { Versuchen Sie, den Gestank } \\
\text { nach Erbrochenem aus den } \\
\text { Teppichen zu entfernen. }\end{array}$ \\
\hline $\begin{array}{l}\text { The aroma of sizzling } \\
\text { bacon filled the kitchen. }\end{array}$ & $\begin{array}{l}\text { Kuhinjo so napolnile von- } \\
\text { jave po cvrčeči slanini. }\end{array}$ & $\begin{array}{l}\text { Das Aroma von brutzeln- } \\
\text { dem Speck füllte die Küche. }\end{array}$ \\
\hline $\begin{array}{l}\text { I wish I could bottle the } \\
\text { fragrance of magnolia } \\
\text { blossom as perfume. }\end{array}$ & $\begin{array}{l}\text { Rad bi ustekleničil vonjavo } \\
\text { magnolijinih cvetov kot } \\
\text { parfum. }\end{array}$ & $\begin{array}{l}\text { Ich wünsche mir, ich könnte } \\
\text { den Duft nach Magnolienblü- } \\
\text { ten als Parfum in Fläschchen } \\
\text { abfüllen. }\end{array}$ \\
\hline $\begin{array}{l}\text { The stench of burning rub- } \\
\text { ber was in the air for days. }\end{array}$ & $\begin{array}{l}\text { Smrad po zažgani gumi je } \\
\text { še več dni ostal v zraku. }\end{array}$ & $\begin{array}{l}\text { Der Gestank nach ver- } \\
\text { branntem Gummi lag noch } \\
\text { tagelang in der Luft. }\end{array}$ \\
\hline $\begin{array}{l}\text { His lungs were filled with } \\
\text { the malodour of diesel } \\
\text { fumes. }\end{array}$ & $\begin{array}{l}\text { Pljuča mu je napolnil } \\
\text { smrad po dizelskem } \\
\text { gorivu. }\end{array}$ & $\begin{array}{l}\text { Seine Lungen füllten sich } \\
\text { mit dem Gestank von } \\
\text { Dieseldämpfen. }\end{array}$ \\
\hline $\begin{array}{l}\text { The old pharmacy was } \\
\text { odorous of herbs and flow- } \\
\text { ers. }\end{array}$ & $\begin{array}{l}\text { Stara lekarna, dišseča po } \\
\text { zeliščih in cvetju ... }\end{array}$ & $\begin{array}{l}\text { Die alte Apotheke, } \\
\text { wohlriechend nach } \\
\text { Kräutern und Blüten ... }\end{array}$ \\
\hline $\begin{array}{l}\text { Her clothes were redolent } \\
\text { of moth balls and cedar } \\
\text { closets. }\end{array}$ & $\begin{array}{l}\text { Njena oblačila, vonjajoča } \\
\text { po naftalinu in omarah iz } \\
\text { cedrovine ... }\end{array}$ & $\begin{array}{l}\text { Ihre Kleider, riechend } \\
\text { nach Mottenkugeln und } \\
\text { Zedernholzschränken ... }\end{array}$ \\
\hline $\begin{array}{l}\text { She ran out of the dirty } \\
\text { room reeky of stale ciga- } \\
\text { rettes. }\end{array}$ & $\begin{array}{l}\text { Pobegnila je iz umazane } \\
\text { sobe, zaudlarjajoče po ci- } \\
\text { garetnem dimu. }\end{array}$ & $\begin{array}{l}\text { Sie rannte aus dem schmut- } \\
\text { zigen, nach Zigarettenrauch } \\
\text { stinkendem Zimmer. }\end{array}$ \\
\hline $\begin{array}{l}\text { Its blooms, deliciously scent- } \\
\text { ed of orange blossom ... }\end{array}$ & $\begin{array}{l}\text { Cvetje, čudovito dišseče po } \\
\text { pomarančnih cvetovih ... }\end{array}$ & $\begin{array}{l}\text { Die Blumen, herrlich duf- } \\
\text { tend nach Orangenblüten, }\end{array}$ \\
\hline
\end{tabular}


Naturally, one can find exceptions (e.g. the noun "aroma" in Slovene regularly combines with the non-prepositional genitival case, as in aroma sveže kave/the aroma of fresh coffee; the German nouns Aroma and Gestank in the above examples are combined with the preposition von if the source of the odour is immediately present), yet the pattern which emerges from the illustrative examples above seems distinct enough.

The finding that prepositions in collocations are not devoid of content, but contribute a certain content to the meaning of the collocational base, even if their content is even more abstract and difficult to define than that of prepositions used in free combinations (which, per definition, tend to have more general and dispersed meanings than lexical words with their lexical meanings), is particularly helpful for language learners and non-native speakers: in the apparent chaos of word combinations, there seem to appear certain patterns which may make easier the memorizing of prepositional collocations, and thus in general improve the quality and naturalness of the texts they produce. 


\section{References}

Allerton, D. J., Valency and the English Verb. London, Academic Press. 1982.

BAHNS, J., Kollokationen als lexicographisches Problem. Eine Analyse allgemeiner und spezieller Lernerwörterbücher des Englischen. In: Lexicographica, Series maior 74. Tübingen, Max Niemeyer. 1996.

BAJEC, A., Besedotvorje slovenskega jezika IV. In: Predlogi in predpone. Ljubljana, SAZU. 1959.

BENSON, M., The Structure of the Collocational Dictionary. In: International Journal of Lexicography II/1. 1989, $1-14$.

Benson, M., Benson, E., ILson, R., The BBI Dictionary of English Word Combinations. Amsterdam/Philadelphia, John Benjamins. 1997.

BoHoRIč, A., Arcticae horulae succisivae (Zimske urice proste). Wittenberg, 1584. ed. J. Toporišič. Maribor, Obzorja. 1987.

ColLinge, N. E. et. al. eds., An Encyclopaedia of Language. London/New York, Routledge. 1990.

CouRTney, R., Longman Dictionary of Phrasal Verbs. Harlow, Essex, Longman. 1983.

Dixon, R. M. W., A New Approach to English Grammar, on Semantic Principles. Oxford, Clarendon Press. 1991.

DulaR, J., Priglagolska vezava v slovenskem knjižnem jeziku (20. stoletja): Ph. D. diss. Ljubljana, FF. 1982.

DULAR, J., Združena vezava v desni vezljivosti slovenskega glagola. In: Jezik in slovstvo, XXIX/8. 1983/84, 289-293.

EMONs, R., Valenzen englischer Prädikatsverben. Tübingen, Max Niemeyer. 1974.

EMONs, R., Valenzgrammatik für das Englische. Tübingen, Max Niemeyer. 1978.

Gutsman, O., Windifche Sprachlehre verfa Jet von Oswald Gutsman. Gratz. 1777, 81-133.

Hausmann, F. J., Wortschatzlernen ist Kollokationslernen. In: Praxis des neusprachlichen Unterrichts 31: 1984, 395-406.

Hausmann, F. J., Kollokationen im deutschen Wörterbuch: ein Beitrag zur Theorie des lexikographischen Beispiels. In: Lexikographie und Grammatik. eds. H. Bergenholtz in J. Mugdan. Tübingen, Max Niemeyer. $1985,118-129$.

HeLbig, G., BuschA, J., Deutsche Grammatik. Ein Handbuch für den Ausländerunterricht. Leipzig, VEB Verlag Enzyklopädie. 1984.

Helbig, G., Probleme der Valenz- und Kasustheorie. Tübingen, Max Niemeyer Verlag. 1992.

HeLbig, G., Schenkel, W., Wörterbuch zur Valenz und Distribution deutscher Verben. Leipzig, VEB Bibliographisches Institut. 1975.

HeRBST, T., Untersuchungen zur Valenz englischer Adjektive und ihrer Nominalisierungen. Tübingen, Narr. 1983.

HERBST, T. A Valency Model for Nouns in English. In: $J L$ 24. 1988, 265-301.

HeRBSt, T., What Are Collocations: Sandy Beaches or False Teeth? In: English Studies 4. 1996, 379-393.

Herbst, T., RoE, I., How Obligatory Are Obligatory Complements? An Alternative Approach to the Categorization of Subjects and Other Complements in Valency Grammar. In: English Studies 2. 1996, 179-199.

KRIŽAJ ORTAR, M., Glagolska vezljivost (na podlagi korpusa črke b v SSKJ). B. A. diss. Ljubljana, FF. 1981.

KRIŽAJ ORTAR, M., Glagolska vezljivost. In: Slavistična revija XXX/2. 1982, 189-213.

KRIŽAJ ORTAR, M., Vezljivost: iz pomena v izraz. In: XXV. seminar slovenskega jezika, literature in kulture. Ljubljana. 1989, 129-140.

Kunst Gnamuš, O., Pomenska sestava povedi. Ph.D.diss. Ljubljana, FF. 1981.

LEROT, J., Die verbregierten Präpositionen in Präpositionalobjekten. In: Satzglieder im Deutschen: Vorschläge zur syntaktischen, semantischen und pragmatischen Fundierung, ed. W. Abraham. Tübingen, Narr. 1982, 261-291.

LindSTROMBERG, English Prepositions Explained. Amsterdam/Philadelphia, John Benjamins. 1997.

Lyons, J., Introduction to Theoretical Linguistics. Cambridge, Cambridge University Press. 1968.

MatTHews, P., Syntax. Cambridge, Cambridge University Press. 1981.

OREŠNIK, J., Udeleženske vloge v slovenščini. Ljubljana, SAZU. 1992.

Palmer, F. R., The English Verb. 2nd ed. Harlow, Essex, Longman. 1988.

PAwley, A., Syder, F. H., Two Puzzles of Linguistic Theory: Nativelike Selection and Nativelike Fluency. In: Language and Communication. Applied Linguistics and Language Study, Ur. eds J. C. Richards and R. W. Schmidt. Harlow, Essex, Longman. 1983, 191-226.

QUIRK, R. et al. eds., A University Grammar of English. Harlow, Essex, Longman. 1973.

QUIRK, R. et al. eds., A Comprehensive Grammar of the English Language. Harlow, Essex, Longman. 1985.

vON RANDOW, E., Valente Substantive des Englischen. Tübingen, Narr. 1986.

SAMARDžIJA, M., Valentnost glagola u suvremenom hrvatskom književnom jeziku. Ph. D. diss. Zagreb, FF. 1986.

SCHRÖDER, J., Lexikon deutscher Präpositionen. Leipzig, VEB Verlag Enzyklopädie. 1986.

SiCHERL, E., Predložne kolokacije v slovenščini in angleščini. Ph. D. diss. Ljubljana, FF. 1999.

SiCHERL, E., On the Content of Prepositions in Prepositional Collocations. In: English Language Overseas Perspectives and Enquiries: Studies in the English Language and Literature in Slovenia I/1-2. 2004, 37-46. 
SincLaIR, J., ed., Collins Cobuild English Guides 1: Prepositions. London, HarperCollins. 1991.

SincLAIR, J., ed., Collins Cobuild English Dictionary. London, HarperCollins. 1995.

Slovar slovenskega knjižnega jezika (SSKJ) I-V. Ljubljana, DZS. 1970, 1975, 1979, 1985, 1991.

SOMERs, H., On the Validity of the Complement-Adjunct Distinction in Valency Grammar. In: Linguistics 22. 1984, 507-530.

ŠveDova, N. Ju., Russkaja grammatika II. (Sintaksis). Moskva, Nauka. 1980.

TESNIÈRE, L., Éléments de syntaxe structurale. Paris, Klincksieck. 1959.

TOPORIšič, J., Slovenski knjižni jezik I-IV (SKJ). Maribor, Obzorja. 1965-1970.

TOPORIšř̌, J., Slovenska slovnica. Maribor, Obzorja. 1976.

ToporIšlč, J., Nova slovenska skladnja (NSS). Ljubljana, DZS. 1982.

TOPORIšřč, J., Prva slovenska skladnja. In: Slavistična revija XXXII/3. 1984, 159-181.

ToPorIšř̌, J., Enciklopedija slovenskega jezika (ESJ). Ljubljana, Cankarjeva založba. 1992.

VIDOvič MuHA, A., Nova slovenska skladnja J. Toporišiča. In: Slavistična revija XXXII/2. 1984, 142-155.

VIDOvič MuHA, A., Glagolske sestavljenke - njihova skladenjska podstava in vezljivostne lastnosti (Z normativnim slovensko-nemškim vidikom). In: Slavistična revija XLI/1. 1993, 161-192.

VinCENOT, C., Essai de Grammaire Slovène. Ljubljana, MK. 1975.

ŽELE, A., Vezljivost $v$ slovenskem knjižnem jeziku. Linguistica et philologica. Ljubljana, Založba ZRC, ZRC SAZU. 2001.

Žıc Fuchs, M., Znanje o jeziku i znanje o svijetu (Semantička analiza glagola kretanja u engleskom jeziku). Ph. D. diss. Zagreb, FF. 1991. 


\section{Povzetek \\ PREDLOŽNE ZVEZE OZ. PREDLOŽNOMORFEMSKOST V SLOVENŠČINI IN ANGLEŠČINI: TEORETIČNI IN KONTRASTIVNI VIDIK}

Predložnomorfemskost kot aktualna stalnica različnih jezikovnih sistemov vedno znova zahteva tudi aktualne teoretične opredelitve - zlasti povedne, širše informativne in uporabne so kontrastivne obravnave. Izhodiščno je $\mathrm{z}$ aktualno slovensko-angleško jezikoslovno terminologijo komentirana predložnomorfemskost $\mathrm{v}$ slovenščini. Potem je kontrastivno, $\mathrm{z}$ vidika prevajanja in žive vsakodnevne prakse, predstavljena problematika doseganja logične in hkrati normativno ustrezne (ne)idiomatične rabe predložnih morfemov v slovenščini, angleščini in nemščini.

V slovenščini kljub prevladujoči usmeritvi v neposrednejše tožilniško izražanje težnja po natančnosti in analitičnosti sporočanega hkrati vodi tudi k pogostejši predložnomorfemski uporabi glagolov. Kako glagolski pomen odloča o izbiri predložnega morfema kažejo npr. zgledi delati na projektu (pov. dol.) : govoriti za njega / govoriti o njem (obvezno dol.) : klestiti s šibo (neobvezno dol.). Prosti glagolski morfem je leksikalizirani kot del pomenskosestavinskosti glagolov v smislu, da jo sotvori (leksikalizacija) in hkrati del glagolskega leksema in glagolske vezljivosti, ali neleksikalizirani, ko pomensko izhaja vsaj iz enega pomena glagolskega leksema in izraža njegovo pomensko- in strukturnoskladenjsko vezljivost ter je zato del povedkove vezljivosti; izven vezljivosti ostajajo še obglagolski vezavnodružljivi predložni morfemi. V anglo-ameriškem jezikoslovju se je v zadnjih desetletjih uveljavila delitev predložnih zvez na proste predložne zveze in slovnične/predložne kolokacije; kolokacije so opredeljene kot povsem naravno pomensko- in strukturnoskladenjsko povezovanje besed v smislu vzajemnega pomensko-skladenjskega pričakovanja besed (mutual expectancy of words). $\mathrm{V}$ obeh primerih pa so s prostimi morfemi navadno ubesedene tiste pomenske sestavine, ki so tako pomensko- kot strukturnoskladenjsko udeležene pri vezljivosti. S prostimi morfemi so torej tudi strukturnoskladenjsko izražene intenčne/vezljivostne pomenske sestavine glagolov. Tako npr. predložni morfem na poudari pomensko sestavino 'pričakovanja' v zvezah kot pripraviti se na, čakati na, upati na ipd.; v angleščini imamo podobnopomenske predložne kolokacije $\mathrm{s}$ for $\mathrm{v}$ primerih kot prepare for, wait for, hope for ipd. in še $\mathrm{v}$ nemščini $\mathrm{z}$ auf $\mathrm{v}$ primerih tipa sich vorbereiten auf, warten auf, hoffen auf ipd. Dejstvo je, da je ravno pri vezljivosti precej velika interferenca govorci si vezljivosti v materinščini niti ne uzavestijo, zato vezljivostne vzorce prenesejo tudi v jezik prevoda. 